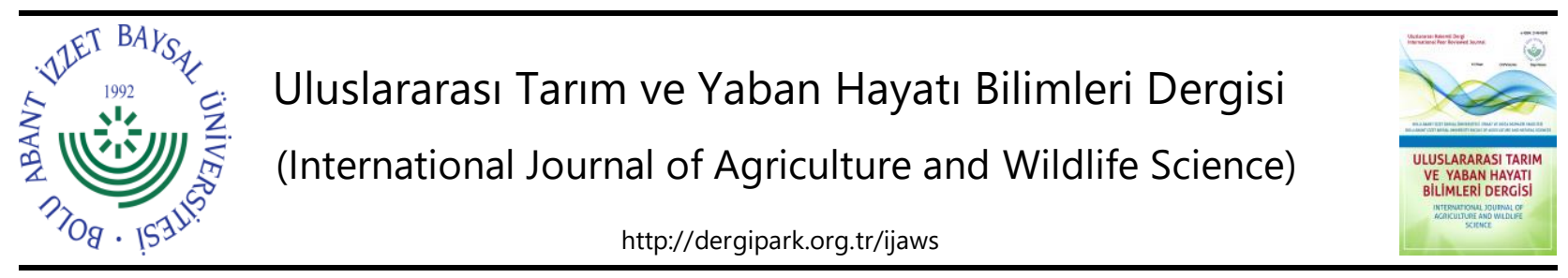

Araştırma Makalesi

\title{
Doğu Anadolu'nun Kuru Şartlarında Farklı Kinoa (Chenopodium quinoa Willd.) Çeşitlerinin Kaba Yem Üretimlerinin Belirlenmesi
}

\author{
Mustafa Tan $^{1 *}, \quad$ Süleyman Temel ${ }^{2}$ \\ ${ }^{1}$ Trakya Üniversitesi Havsa Meslek Yüksekokulu Park ve Bahçe Bitkileri Bölümü, Edirne \\ ${ }^{2}$ Iğdır Üniversitesi Ziraat Fakültesi Tarla Bitkileri Bölümü, Iğdır
}

Geliş tarihi (Received): 22.05.2020

Kabul tarihi (Accepted): 01.07.2020

\section{Anahtar kelimeler: \\ Chenopodium quinoa, kinoa, lokasyon, morfolojik özellikler, ot verimi, ham protein verimi}

\begin{abstract}
Özet. Kinoa (Chenopodium quinoa Willd.) yüksek rakımlarda, kurak ve tuzlu topraklar gibi ekstrem şartlarda başarı ile yetiştirilebilen bir alternatif bitkidir. Bu araştırma Doğu Anadolu Bölgesinin Erzurum ve Iğdır gibi iki farklı lokasyonunda 10 farklı kinoa çeşidinin kuru şartlardaki kaba yem üretim potansiyelini belirlemek amacıyla yürütülmüştür. Araştırma 2015 ve 2016 yıllarında şansa bağlı tam bloklar deneme planında 4 tekerrürlü olarak kurulmuştur. Her bir lokasyonda çeşitlerin kuru madde verimi, çiçeklenmeye kadar geçen süre, bitki boyu, yaprak alan indeksi, sap kalınlığı ve ham protein verimleri incelenmiştir. İki yıllık araştırma sonuçlarına göre Erzurum kuru şartlarında kinoa çeşitlerinin verimleri oldukça düşük (213.5-337.8 $\left.\mathrm{kg} \mathrm{da}^{-1}\right)$ bulunmuştur. Buna karşılık Iğdır şartlarında bütün çeşitler yeterli verim vermişlerdir (585.4-999.0 kg da-1). Mint Vanilla, Oro de Valle, Sandoval Mix, Red Head, Cherry Vanilla, French Vanilla ve Rainbow çeşitleri yüksek kuru madde ve ham protein verimine sahip olmuşlardır. Bu sonuçlara göre Erzurum kuru şartlarında kinoa yetiştiriciliğinin uygun olmadığı, Iğdır şartlarında ise başta Mint Vanilla, Oro de Valle ve Sandoval Mix çeşitleri olmak üzere rahatlıkla yetiştirilebileceği belirlenmiştir.
\end{abstract}

\section{Determination of Roughage Production of Different Quinoa (Chenopodium quinoa Willd.) Varieties in Dry Conditions of Eastern Anatolia}

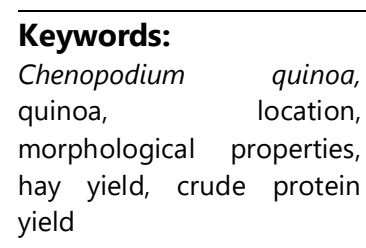

Abstract. Quinoa (Chenopodium quinoa Willd.) is an alternative plant that can be successfully grown at high altitudes, in extreme conditions such as arid and saline soils. This research was carried out to determine the potential of 10 different quinoa varieties in two different locations of East Anatolia Region such as Erzurum and Iğdır in dry conditions. The research was established in 2015 and 2016 in the randomized complete blocks design with four replications. In each location, dry matter yield, time to flowering, plant height, leaf area, stem thickness, and crude protein yields of the varieties were examined. According to the results of two years of research, the yield of quinoa varieties was quite low (213.5-337.8 kg da-1) in Erzurum dry conditions. In contrast, all varieties gave sufficient yield under lğdır conditions (585.4-999.0 kg da-1). Mint Vanilla, Oro de Valle, Sandoval Mix, Red Head, Cherry Vanilla, French Vanilla, and Rainbow varieties had a high dry matter and crude protein yields. According to these results, it was determined that quinoa cultivation was not suitable in Erzurum dry conditions and that it could be grown easily under the conditions of Iğdır, especially Mint Vanilla, Oro de Valle and Sandoval Mix varieties. 


\section{Giriş}

Kinoa (Chenopodium quinoa Willd) son yıllarda ülkemizde tarımı yaygınlaşan alternatif ürünlerden birisidir. Ekstrem şartlara uyum sağlaması ve tohumlarının yüksek besleme değerine sahip olması gibi özellikleri ile ön plana çıkmaktadır (Tan ve Temel, 2019). Tohumları bulgur ve pirinç gibi insan beslenmesinde kullanılmaktadır. Tohumu glüten içermediği için glütene duyarlılığı olan çölyak hastaları için güvenli bir besindir (Jacobsen, 1993). Buğday, mısır ve pirinçten daha fazla protein içerir (Cardozo ve Tapia, 1979). Bu bitkinin tohumlarında ham protein içeriği ortalama \%13 civarında olup, çeşitlere bağlı olarak \%7.5 ile \%22.1 arasında değişmektedir (Cardozo ve Tapia 1979; Kır ve Temel, 2016). Bu yüzden kinoanın çok iyi bir protein kaynağı olduğu kabul edilmektedir. Ayrıca; mineral, lif, A, B, C ve E vitaminlerince iyi bir kaynaktır. Tahıllardan yaklaşık 2 kat daha fazla lif içeren kinoa, beslenme uzmanları tarafından ısrarla önerilen bir gıda maddesidir (Tan ve Yöndem, 2013).

Bu bitkinin tarımı Güney Amerika'da 4200 m rakıma kadar çıkabilmektedir (FAO, 2011). Ancak anavatanında 4000 m'nin üzerinde yetişiyor olması dünyanın diğer bölgelerinde de aynı yükseklikte yetişeceği anlamına gelmez. Çünkü bitkilerin adaptasyonunda çok sayıda çevresel faktör birlikte etkili olmaktadır. Kazık kök sistemine sahip olan kinoa kurak şartlarda iyi bir kök sistemi geliştirerek kurağa dayanıklılık gösterir (Gonzales ve ark., 2009). Yüksek su kullanım etkinliğine sahip olduğundan 100-200 mm yağış alan yerlerde bile yetiştirildiği ifade edilmektedir (Garcia ve ark., 2003; Bertero ve ark., 2004). Derin ve yoğun kök sisteminin yanında dinamik stoma yapısı, kalın çeperli hücre duvarları ve özel kabarcıklı bezeler gibi su kaybını engelleyen mekanizmalara sahiptir (Garcia ve ark., 2015). Kinoa büyüme mevsimi süresince 250-400 mm su tüketir, ihtiyaç duyduğu su miktarı \%50 seviyesine kadar kısıtlandığında veriminde önemli bir azalma olmaz (Akçay, 2017). Kır ve Temel (2016) lğdır kuru koşullarında kinoadan $210 \mathrm{~kg} \mathrm{da}^{-1}$ 'a kadar tane verimi alınabildiğini belirlemişlerdir.

Kinoa daha çok insan beslenmesinde kullanılmak üzere tane üretimi için yetiştirilen bir bitkidir. Ancak bu bitki tuzlu ve kurak topraklarda kaba yem bitkisi olarak da yetiştirilebilmektedir. Kinoa otu ve samanı Güney Amerika'da sığır, koyun, at ve domuzların beslenmesinde yüzyıllardır kullanılmaktadır (FAO, 1994). Uygun genotiplerin kullanılmasıyla yüksek miktarda ot verimi alınabilmektedir. Doğru çeşit seçilerek iyi bakım yapılan tarlalarda kuru

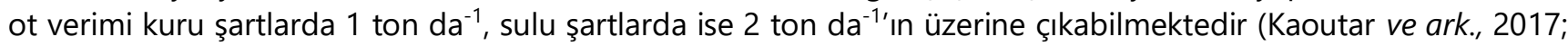
Tan ve Temel, 2017 ve 2018; Temel ve Keskin, 2019a; Temel ve Şurgun, 2019; Temel ve Yolcu, 2020). Kinoa otu çeşit, ekim ve hasat zamanlarına bağlı olarak \%13-22 oranında ham protein içermekte olup, sindirilme oranı \%6374'tür (Van Schooten ve Pinxterhuis, 2003; Üke ve ark., 2017; Temel ve Keskin, 2019b; Temel ve Yolcu, 2020). Kinoadan üretilen ot yeşil olarak veya silaj yapılarak hayvanlara yedirilmektedir.

Kinoa sahip olduğu binlerce çeşit, popülasyon ve yabani formuyla çok geniş bir genetik çeşitliliğe sahiptir. Bu zenginlik çevresel stres faktörlerine dayanıklılık sağlamakta ve bunun sonucunda sorunlu alanlar da dahil çok farkı ekolojilerde yetiştiriciliğini mümkün kılmaktadır. Bu nedenle farklı ekolojilerde farklı amaçlar için yapılacak üretimler için uygun çeşitlerin belirlenmesi gereklidir. Bu araştırma Doğu Anadolu'nun farklı özelliklere sahip Erzurum ve Iğdır illerinde değişik kinoa çeşitlerinin kuru şartlarda ot üretimini belirlemek amacıyla planlanmıştır.

\section{MATERYAL VE METOT}

Araştırma Doğu Anadolu Bölgesinin iki farklı lokasyonu olan Erzurum ve lğdır illerinde 2015 ve 2016 yıllarında yürütülmüştür. Erzurum'daki denemeler Atatürk Üniversitesi Ziraat Fakültesi, Iğdır'daki denemeler ise Iğdır Üniversitesi Ziraat Fakültesi deneme alanlarında kuru şartlarda yürütülmüştür. İki farklı lokasyonda 10 kinoa (Chenopodium quinoa Willd.) çeşidi ot verimi ve bazı özellikler yönünden incelenmişlerdir. İncelemeye alınan çeşitler Peru, ABD, İngiltere ve Danimarka orijinli materyallerdir (Çizelge 1).

Çizelge 1. Araştırmada kullanılan kinoa çeşitleri ve orijinleri.

Table 1. Quinoa varieties and their origins used in the research.

\begin{tabular}{llll}
\hline Çeşitler & Orijin & Çeşitler & Orijin \\
\hline Titicaca & Danimarka & French Vanilla & USA \\
Qhaslala Blanca & Peru & Mint Vanilla & USA \\
Moqu-Arrochilla & Peru & Oro de Valle & USA \\
Sandoval Mix & İngiltere & Rainbow & USA \\
Cherry Vanilla & USA & Red Head & USA \\
\hline
\end{tabular}

Araştırma her iki lokasyonda da şansa bağlı tam bloklar deneme desenine göre 4 tekerrürlü olarak ekilmiştir. Ekimler Iğdır'da 29 Mart 2015 ve 6 Nisan 2016; Erzurum'da ise 5 Mayıs 2015 ve 10 Mayıs 2016 tarihlerinde yapılmıştır. Sıra aralığı 35 cm, ekim normu ise $250-300 \mathrm{~g} \mathrm{da}^{-1}$ olacak şekilde ayarlanmıştır (Tan ve Yöndem, 2013; 
Geren ve ark., 2015). Toprak tahlilleri göz önüne alınarak12.5 kg N da-1 dozunda azotlu ve $8 \mathrm{~kg} \mathrm{P}_{2} \mathrm{O}_{5} \mathrm{da}^{-1} \mathrm{dozunda}^{-1}$ fosforlu gübre uygulanmıştır (Tan ve Yöndem, 2013; Geren, 2015; Şurgun ve Temel, 2019). Denemelere su verilmemiş, sadece çapalama ve koparma şeklinde yabancı ot mücadelesi yapılmıştır.

Bitkiler çiçeklenme başlangıcı dönemine ulaştığı zaman kök boğazından biçilerek hasat edilmişlerdir (Tan ve Yöndem, 2013). Hasat edilen bitkiler torbalara doldurularak önce açık havada, daha sonra $65{ }^{\circ} \mathrm{C}^{\prime}$ lik kurutma fırınında sabit ağırlığa gelinceye kadar kurutularak kuru madde verimleri hesaplanmıştır. Çiçeklenme süresi; ekimden çiçeklenmeye kadar geçen gün sayısı olarak kaydedilmiştir. Hasat esnasında parsellerden rastgele alınan 10 bitkide kök boğazı ile salkımın en uç noktası ölçülerek bitki boyu belirlenmiştir. Bu bitkilerde yapraklar ayrılarak yapak alan ölçer yardımılla önce toplam yaprak alanları ve daha sonra basit bir eşitlik yardımıyla yaprak alan indeksleri $\left(\mathrm{m}^{2}\right)$ bulunmuştur. Saplar alttan itibaren 2. ve 3. yaprak arasındaki noktasından kumpas yardımı ile ölçülerek sap kalınlıkları belirlenmiştir. Her parselden alınan kurutulmuş bitkiler öğütülerek Mikro Kjeldahl metoduyla önce toplam \% N içeriği ve sonra 6.25 katsayısıyla çarpılarak ham protein oranları belirlenmiştir (AOAC, 1997). Daha sonra bu oranlar kuru madde verimleri ile çarpılarak ham protein verimleri $\left(\mathrm{kg} \mathrm{da}^{-1}\right)$ hesaplanmıştır. Elde edilen iki yıllık ortalama veriler MSTAT-C paket programı yardımıyla varyans analizine tabi tutulmuş, ortalamalar arasındaki farklılıklar 0.05 intimal seviyesinde LSD çoklu karşılaştırma testi ile harflendirilmiştir.

Araştırmanın yürütüldüğü Erzurum ve Iğdır illerinin her ikisi de Doğu Anadolu coğrafi bölgesinde yer almasına rağmen birbirilerinden çok farkı ekolojik özelliklere sahiptirler. Erzurum bölgenin en yüksek rakımlı ili olup, denizden yüksekliği 1860 m'dir. Genel olarak kış ayları soğuk ve kar yağışlı, yaz ayları ise nispeten serin ve kurak geçmektedir. Ilin en önemli tarımsal özelliklerinden birisi bitki yetiştirme sezonunun kısa olmasıdır. Iğdır ili ise Doğu Anadolu Bölgesi içerisinde mikroklima özelliğe sahip ve Erzurum'dan çok farklı bir ildir. Bitki yetiştirme sezonu uzundur. Rakımı 876 m olan Iğdırın yaz ayları sıcak ve kurak olup, buharlaşma oranı yüksektir. Erzurum ve Iğdır lokasyonlarına ait deneme aylarındaki sıcaklık ve yağış değerleri Çizelge 2'de verilmiştir (MGM, 2017). Araştırmanın 2015 yııında hem Erzurum'da hem de Iğdır'da sıcaklık 2016 yılı ve uzun yıllar ortalamasından daha yüksek gerçekleşmiştir. Buna karşıık 2016 yılı her iki lokasyonda da 2015'e göre daha yağışlı seyretmiştir. Iğdır ili 2015 yılı belirgin olarak kurak bir yıl olarak kaydedilmiştir $(75.4 \mathrm{~mm})$.

Çizelge 2. Erzurum ve Iğdır illerinin 2015 ve 2016 yılları ile uzun yıllar ortalaması (UYO) deneme aylarına ait sıcaklık ve yağış değerleri.

Table 2. Temperature and precipitation values of Erzurum and Iğdır provinces for the years of 2015 and 2016 and their longterm average (LTA) trial months.

\begin{tabular}{|c|c|c|c|c|c|c|c|c|c|c|c|c|}
\hline \multirow{3}{*}{ Aylar } & \multicolumn{6}{|c|}{ Sıcaklık $\left({ }^{\circ} \mathrm{C}\right)$} & \multicolumn{6}{|c|}{ Yağış (mm) } \\
\hline & \multicolumn{3}{|c|}{ Erzurum } & \multicolumn{3}{|c|}{ Iğdır } & \multicolumn{3}{|c|}{ Erzurum } & \multicolumn{3}{|c|}{ Iğdır } \\
\hline & UYO & 2015 & 2016 & UYO & 2015 & 2016 & UYO & 2015 & 2016 & UYO & 2015 & 2016 \\
\hline Nisan & 5.5 & 5.3 & 7.1 & 13.3 & 16.4 & 14.7 & 51.4 & 88.6 & 39.4 & 34.5 & 44.1 & 20.1 \\
\hline Mayıs & 10.6 & 10.6 & 10.5 & 17.8 & 21.3 & 18.7 & 70.3 & 81.5 & 64.8 & 47.1 & 41.5 & 23.5 \\
\hline Haziran & 14.9 & 17.0 & 14.8 & 22.1 & 28.5 & 23.0 & 46.3 & 28.5 & 88.6 & 33.0 & 27.8 & 26.9 \\
\hline Temmuz & 19.3 & 21.2 & 19.0 & 25.9 & 31.8 & 26.2 & 26.0 & 5.8 & 17.8 & 13.8 & 2.0 & 32.0 \\
\hline Top./Ort. & 12.6 & 13.5 & 12.9 & 20.0 & 24.5 & 20.7 & 194.0 & 204.4 & 210.6 & 128.4 & 75.4 & 102.5 \\
\hline
\end{tabular}

UYO: Uzun yillar ortalaması (1990-2014)

Tarla çalışmalarının yürütüldüğü topraklar her iki lokasyonda da killi-tınlı tekstür sınıfına dahildir. Fakat Iğdır lokasyonu toprak özellikleri Erzurum lokasyonuna göre belirgin bir şekilde yüksek elektriksel iletkenlik, pH ve kireç oranına sahiptir. Her iki lokasyonda da topraklar düşük organik madde oranına sahiptir (Çizelge 3) (Kacar, 2012).

Çizelge 3. Deneme alanları topraklarının bazı fiziksel ve kimyasal özellikleri.

Table 3. Some physical and chemical properties of the study area soils.

\begin{tabular}{|c|c|c|}
\hline Toprak Özellikleri & Erzurum & Iğdır \\
\hline Tekstür sınıfı & Killi-tınlı & Killi-tınlı \\
\hline $\mathrm{EC}\left(\mathrm{ms} \mathrm{cm}^{-1}\right)$ & 0.48 & 2.00 \\
\hline $\mathrm{pH}$ & 7.1 & 7.9 \\
\hline Kireç $\left(\% \mathrm{CaCO}_{3}\right)$ & 2.5 & 6.5 \\
\hline Potasyum ( $\left.\mathrm{kg} \mathrm{K}_{2} \mathrm{O} \mathrm{da}{ }^{-1}\right)$ & 138 & 343 \\
\hline Fosfor $\left(\mathrm{kg} \mathrm{P}_{2} \mathrm{O}_{5} \mathrm{da}^{-1}\right)$ & 7.4 & 8.0 \\
\hline Organik madde (\%) & 1.4 & 1.6 \\
\hline
\end{tabular}




\section{BULGULAR VE TARTIŞMA}

Kinoada çiçeklenmeye kadar geçen süre lokasyonlara ve çeşitlere göre önemli seviyede farklılık göstermiştir (Çizelge 4). Erzurum şartlarında 71.9 gün olan çiçeklenmeye kadar geçen süre lğdır şartlarında 80.2 gün olarak gerçekleşmiştir. Erzurum iklim şartlarının daha serin ve nemli (Çizelge 2) olmasına rağmen bitkiler daha erken çiçeklenmişlerdir. Bu durum ekimlerin geç yapılmış olmasından kaynaklanmaktadır. Kinoa kısa gün bitkisi olup, yaz aylarında günlerin kısalması ile birlikte çiçeklenmeye başlamaktadır. Bu nedenle Erzurum şartlarında çiçeklenme daha erken gerçekleşmiştir. Kaya ve Kızıl Aydemir (2020) kinoanın Bilecik şartlarında ortalama 69 günde, Geren ve Güre (2017) İzmir şartlarında 73 günde çiçeklendiğini belirlemişlerdir. Çiçeklenmeye başlama süresi genotiplere göre büyük değişim göstermektedir. Çeşitlerin çiçeklenmesi lokasyonlara göre de farklılık gösterdiği için çeşit x lokasyon interaksiyonu önemli bulunmuştur. Titicaca çeşidi her iki lokasyonda da en erken çiçeklenen materyaldir (68.8 ve 71.8 gün). Moqu Arrochilla çeşidi de erkencilik özelliği göstermiş, Erzurum'da 71.3 günde çiçeklenirken, Iğdır şartlarında 73.5 günde çiçeklenmeye ulaşmıştır. Diğer taraftan Erzurum'da erkenci özellik gösteren Rainbow (70.3 gün) Iğdır şartlarında en son çiçeklenen materyallerden bir olmuştur (86.8 gün). Araştırmada en geç çiçeklenen çeşit Qhaslala Blanca'dır. Bu çeşit Erzurum'da 81.3 gün, Iğdır'da 94.3 günde çiçeklenebilmiştir (Çizelge 4). Kinoada çiçeklenme süresinin materyalin kökenine göre değişim gösterdiği Christiansen ve ark. (2010) tarafından da ortaya konulmuştur.

Çizelge 4. Kinoa çeşitlerinin iki yıllık ortalama çiçeklenme süresi ve bitki boyları ${ }^{1}$.

Table 4. Two-year average flowering period and plant height of quinoa varieties ${ }^{1}$.

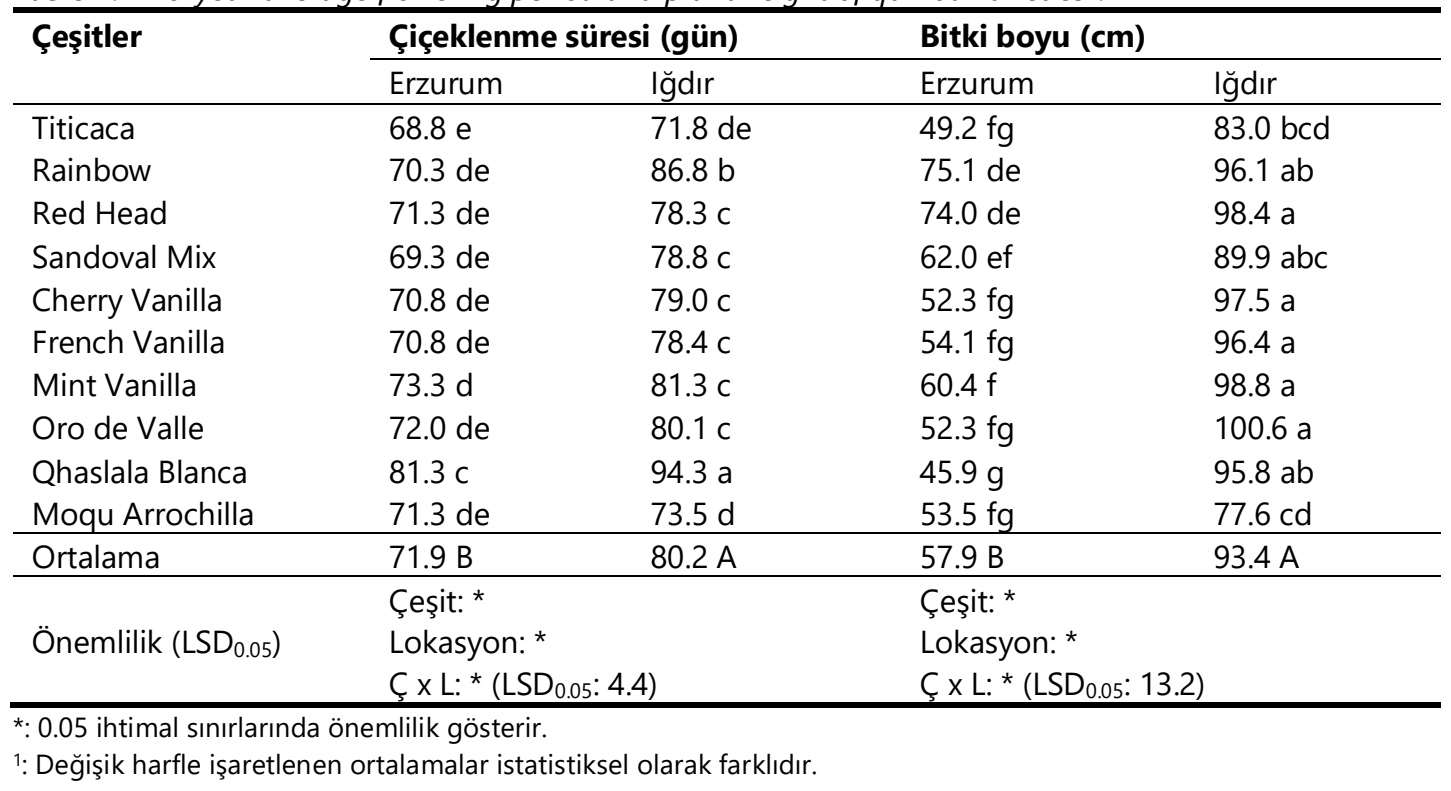

Kinoada bitki boyu, hem çeşitlere ve hem de lokasyonlara göre değişiklikler göstermiş, bunlara ait interaksiyon da önemli bulunmuştur (Çizelge 4). Kinoa saplarının ucunda çiçek açan determinant (sınırlı büyüme yapan) bir bitkidir. Bu nedenle boy uzaması çiçeklenme dönemine kadar gerçekleşmekte, çiçeklenemeden sonra uzama sadece salkımların uzaması şeklinde devam etmektedir. Iğdır şartlarında daha uzun süre gelişme şansı bulan bitkiler daha uzun boylu olmuşlardır. Genel olarak incelendiğinde Raibow ve Red Head çeşitlerinin uzun, Titicaca ve Moqu Arrochilla çeşitlerinin kısa boylu olduğu söylenebilir. Ancak çeşitler lokasyonlara göre farklı performanslar ortaya koymuşlar, bu da çeşit x lokasyon interaksiyonunun önemli çıkmasına sebep olmuştur. Araştırmadaki en kısa bitki boyu $(45.9 \mathrm{~cm})$ Erzurum şartlarında Qhaslala Blanca çeşidinde belirlenmiştir. Bunu yine Erzurum lokasyonunda Titicaca çeşidi $(49.2 \mathrm{~cm})$ takip etmiştir. En uzun bitkiler ise sırasıyla Iğdır lokasyonunda yetiştirilen Oro de Valle $(100.6 \mathrm{~cm})$, Mint Vanilla $(98.8 \mathrm{~cm})$ ve Red Head $(98.4 \mathrm{~cm})$ çeşitlerinde tespit edilmiştir. Genel olarak; daha geçci olan çeşitlerin gelişme süresi uzun olan lğdır lokasyonunda daha uzun boylu oldukları görülmektedir. Farklı lokasyonlarda farklı kinoa genotiplerini inceleyen Pulvento ve ark. (2010) da benzer sonuçlar belirlemişlerdir.

Yaprak alanı indeksi ot kalitesi ve verim için önemli bir parametredir. Yaprak alanı indeksi yüksek olan bitkilerin ot kalitelerinin ve verimlerinin de yüksek olması beklenmektedir. Iğdır şartlarında yetiştirilen bitkiler daha fazla yaprak alan indeksine sahip olmuşlardır (Çizelge 5). Erzurum şartlarında kinoa çeşitleri ortalama $1.63 \mathrm{~m}^{2}$ yaprak alanı indeksi oluştururken, Iğdır şartlarında $5.64 \mathrm{~m}^{2}$ alan üretmişlerdir. Iğdır şartlarında bitkilerin daha uzun gelişme süresine sahip olması ve daha uzun boylu olmaları (Çizelge 4) bu sonucu ortaya çıkarmışır. Çeşitler 
arasında Erzurum şartlarında Sandoval Mix $\left(2.26 \mathrm{~m}^{2}\right)$ ve Rainbow $\left(1.95 \mathrm{~m}^{2}\right)$, Iğdır şartlarında Mint Vanilla $\left(7.22 \mathrm{~m}^{2}\right)$, Red Head $\left(6.32 \mathrm{~m}^{2}\right)$ ve Oro de Valle $\left(6.31 \mathrm{~m}^{2}\right)$ yüksek yaprak alan indeksine sahip olmuşlardır. Bilalis ve ark. (2012) yapılan uygulamalara bağlı olarak kinoada yaprak alan indeksinin 4.47-5.03 $\mathrm{m}^{2}$ arasında değiştiğini belirlemişlerdir. Ruiz ve Bertero (2008) da yıllara (iklim şartları) ve genotiplere göre kinoanın yaprak alan indeksinin değiştiğini bulmuşlardır.

Çizelge 5. Kinoa çeşitlerinin iki yıllık ortalama yaprak alanı indeksi ve sap kalınlıkları1.

Table 5. Two-year average leaf area index and stem thickness of quinoa varieties?.

\begin{tabular}{|c|c|c|c|c|}
\hline \multirow[t]{2}{*}{ Çeşitler } & \multicolumn{2}{|c|}{ Yaprak alan indeksi $\left(\mathrm{m}^{2}\right)$} & \multicolumn{2}{|c|}{ Sap kalınlığı (mm) } \\
\hline & Erzurum & lğdır & Erzurum & lğdır \\
\hline Titicaca & $1.71 \mathrm{de}$ & $4.83 \mathrm{abc}$ & $7.3 \mathrm{~cd}$ & $9.5 \mathrm{abc}$ \\
\hline Rainbow & $1.95 \mathrm{cde}$ & $6.06 \mathrm{a}$ & $9.9 \mathrm{abc}$ & $10.9 \mathrm{abc}$ \\
\hline Red Head & $1.59 \mathrm{e}$ & $6.32 \mathrm{a}$ & $10.1 \mathrm{abc}$ & $10.6 \mathrm{abc}$ \\
\hline Sandoval Mix & $2.26 \mathrm{~b}-\mathrm{e}$ & $6.03 \mathrm{a}$ & $7.9 \mathrm{abc}$ & $11.0 \mathrm{abc}$ \\
\hline Cherry Vanilla & $1.54 \mathrm{e}$ & $4.69 \mathrm{abc}$ & $7.8 \mathrm{bcd}$ & $11.0 \mathrm{abc}$ \\
\hline French Vanilla & $1.43 \mathrm{e}$ & $5.19 \mathrm{ab}$ & $7.3 \mathrm{~cd}$ & $10.6 \mathrm{abc}$ \\
\hline Mint Vanilla & $1.45 \mathrm{e}$ & $7.22 \mathrm{a}$ & $8.3 \mathrm{abc}$ & $10.8 \mathrm{abc}$ \\
\hline Oro de Valle & $1.45 \mathrm{e}$ & $6.31 \mathrm{a}$ & $8.9 \mathrm{abc}$ & $11.4 a b$ \\
\hline Qhaslala Blanca & $1.60 \mathrm{de}$ & $5.21 \mathrm{a}$ & $5.6 \mathrm{~d}$ & $11.8 \mathrm{a}$ \\
\hline Moqu Arrochilla & $1.27 \mathrm{e}$ & $4.54 \mathrm{a}-\mathrm{d}$ & $7.5 \mathrm{bcd}$ & $9.9 \mathrm{abc}$ \\
\hline Ortalama & $1.63 \mathrm{~B}$ & $5.64 \mathrm{~A}$ & $8.1 \mathrm{~B}$ & $10.8 \mathrm{~A}$ \\
\hline \multirow{3}{*}{ Önemlilik (LSD 0.05$)$} & \multicolumn{2}{|l|}{ Çeşit: * } & \multicolumn{2}{|l|}{ Çeşit: * } \\
\hline & \multicolumn{2}{|c|}{ Lokasyon: * } & \multicolumn{2}{|c|}{ Lokasyon: * } \\
\hline & \multicolumn{2}{|c|}{ Ç $\times$ L: * $\left(\operatorname{LSD}_{0.05}: 2.94\right)$} & \multicolumn{2}{|c|}{ Ç $\times$ L: * $\left(\operatorname{LSD}_{0.05}: 3.9\right)$} \\
\hline
\end{tabular}

*: 0.05 ihtimal sınırlarında önemlilik gösterir.

1: Değişik harfle işaretlenen ortalamalar istatistiksel olarak farklıdır.

Iğdır şartlarında yetişen bitkiler Erzurum lokasyonundakilere göre daha kalın saplı olmuşlardır (Çizelge 5). Daha geçci ve daha uzun boylu olan bitkilerde sapların daha kalın olması beklenen bir durumdur. Bunun yanında farklı özellikleri olan çeşitlerin de sap kalınlıkları farklıık göstermiştir. Qhaslala Blanca çeşidi Erzurum şartlarında $5.6 \mathrm{~mm}$ ile en ince saplı çeşit olurken, Iğdır şartlarında yine aynı çeşit $11.8 \mathrm{~mm}$ ile en kalın saplı materyal olmuştur. Bu durum çeşitlerin lokasyonlara göre farklı performans gösterdiklerinin en güzel örneğidir. Red Head çeşidi ise Erzurum'da $10.1 \mathrm{~mm}$ ve Iğdır'da $10.6 \mathrm{~mm}$ ile birbirilerine çok yakın değerlere sahip olmuştur. Kinoada sap kalınlığının genotiplere göre değiştiğini Curti ve ark. (2012) ve Spehar ve de Barros Santos (2005) gibi araştırıcılar da teyit etmişlerdir.

Çizelge 6. Kinoa çeşitlerinin iki yıllık ortalama kuru madde ve ham protein verimleri ${ }^{1}$.

Table 6. Two-year average dry matter and crude protein yields of quinoa varieties'.

\begin{tabular}{|c|c|c|c|c|}
\hline \multirow[t]{2}{*}{ Çeşitler } & \multicolumn{2}{|c|}{ Kuru madde verimi $\left(\mathrm{kg} \mathrm{da}^{-1}\right)$} & \multicolumn{2}{|c|}{ Ham protein verimi $\left(\mathrm{kg} \mathrm{da}^{-1}\right)$} \\
\hline & Erzurum & Iğdır & Erzurum & Iğdır \\
\hline Titicaca & $255.7 \mathrm{bc}$ & $667.4 \mathrm{ab}$ & 44.9 efg & $113.6 \mathrm{abc}$ \\
\hline Rainbow & $337.8 \mathrm{bc}$ & $831.8 \mathrm{a}$ & 56.8 def & 108.9 a-d \\
\hline Red Head & $257.3 \mathrm{bc}$ & $863.4 \mathrm{a}$ & $46.6 \mathrm{efg}$ & $122.0 \mathrm{abc}$ \\
\hline Sandoval Mix & $283.3 \mathrm{bc}$ & $888.5 \mathrm{a}$ & 51.3 efg & $146.4 \mathrm{ab}$ \\
\hline Cherry Vanilla & $243.9 c$ & $857.0 \mathrm{a}$ & $41.7 \mathrm{fg}$ & $143.0 \mathrm{abc}$ \\
\hline French Vanilla & $253.5 \mathrm{bc}$ & 846.8 a & $47.2 \mathrm{efg}$ & $140.2 \mathrm{abc}$ \\
\hline Mint Vanilla & $240.5 \mathrm{c}$ & $999.0 \mathrm{a}$ & $42.2 \mathrm{fg}$ & 158.6 a \\
\hline Oro de Valle & 249.8 bc & $917.5 \mathrm{a}$ & $44.9 \mathrm{efg}$ & $144.1 \mathrm{abc}$ \\
\hline Qhaslala Blanca & $213.5 \mathrm{c}$ & $585.4 \mathrm{abc}$ & $36.7 \mathrm{~g}$ & $93.2 c-f$ \\
\hline Moqu Arrochilla & $233.7 c$ & $592.6 \mathrm{abc}$ & $38.9 \mathrm{~g}$ & $97.5 \mathrm{~b}-\mathrm{e}$ \\
\hline Ortalama & $256.9 \mathrm{~B}$ & $804.9 \mathrm{~A}$ & $45.1 \mathrm{~B}$ & $126.8 \mathrm{~A}$ \\
\hline Önemlilik (LSD 0.05$)$ & $\begin{array}{l}\text { Çeşit: * } \\
\text { Lokasyor } \\
\text { Ç x L: * (L }\end{array}$ & 21.2) & $\begin{array}{l}\text { Çeşit: * } \\
\text { Lokasyor } \\
\text { Ç x L: * }\end{array}$ & \\
\hline
\end{tabular}

*: 0.05 ihtimal sınırlarında önemlilik gösterir.

1: Değişik harfle işaretlenen ortalamalar istatistiksel olarak farklıdır.

Araştırmada kinoanın kuru madde verimleri lğdır şartlarında (804.9 kg da $\left.{ }^{-1}\right)$ Erzurum şartlarına (256.9 kg da $\left.{ }^{-1}\right)$ göre belirgin olarak daha yüksek bulunmuştur (Çizelge 6). Bu sonuçlar Erzurum ekolojisinin kuru şartlarında kinoa 
yetiştiriciliğine uygun olmadığını ortaya koymaktadır. Çünkü yeterli çimlenmenin sağlanması için ekimler Mayıs ayı içerisinde yapılmakta, yaz sıcakları başlayınca bitkiler yeterince gelişemeden çiçeklenmektedirler. Bu nedenle kuru şartlarda yapılan yetiştiricilikte yeterli ürün alınamamaktadır. Iğdır ekolojisinde ekimler erken yapıldığı için Nisan ve Mayıs aylarında bitkiler yeterli gelişme göstermekte ve verimler yükselmektedir. Ayrıca bölge topraklarının hafif tuzlu olması da kinoanın daha iyi performans göstermesine katkı yapmış olabilir (Jacobsen, 2003). Bu lokasyonda çeşitlerin kuru madde verimleri $585.4 \mathrm{~kg} \mathrm{da}^{-1}$ ile $999.0 \mathrm{~kg} \mathrm{da}^{-1}$ arasında değişmiş ve materyallerin tamamı araştırmadaki en yüksek verimli gruba dahil olmuşlardır. En verimli çeşitler Mint Vanilla, Oro de Valle ve Sandoval Mix olarak belirlenmiş̧ir. Farklı bölgelerde yapılan çalışmalar kinoa çeşitlerinin farklı kuru madde verimi performansları gösterdiğini ortaya koymuştur (Spehar ve Barros Santos, 2005; Üke ve ark., 2017; Kaya ve Kızıl Aydemir, 2020).

Iğdır şartlarında kuru madde verimlerinin yüksek olması ham protein verimlerine yansımış ve lğdır'da ortalama $126.8 \mathrm{~kg} \mathrm{da}^{-1}$ ham protein verimi elde edilmiştir. Buna karşılık Erzurum lokasyonunda ortalama ham protein verimi $45.1 \mathrm{~kg} \mathrm{da}^{-1}$ 'dır. Erzurum şartlarında en yüksek ham protein verimi $56.8 \mathrm{~kg} \mathrm{da}^{-1}$ (Rainbow) olarak belirlenirken Iğdır şartlarında ham protein verimleri $93.2 \mathrm{~kg} \mathrm{da}^{-1}$ ile $158.6 \mathrm{~kg} \mathrm{da}^{-1}$ arasında değişmiştir. En yüksek değerler Mint Vanilla, Sandoval Mix, Oro de Valle, Cherry Vanilla ve French Vanilla çeşitlerinde belirlenmiştir. Ham protein verimi ham protein oranı ve kuru madde verimlerinden hesaplandığı için, bu parametreleri etkileyen bütün faktörler ham protein verimine yansımaktadır. Ama özellikle kuru madde veriminin ham protein veriminde çok etkili olduğu görülmektedir. Çeşitler arasındaki farklılığı Kaya ve Kızıl Aydemir (2020) de belirlemişlerdir.

\section{SONUÇ}

Araştırmadan elde edilen iki yıllık sonuçlar kinoanın Doğu Anadolu kuru şartlarında lokasyonlara göre farklı sonuçlar verdiğini ortaya koymuştur. Erzurum'da kuru şartlarda kinoa yetiştiriciliğinin uygun olmadığı görülmektedir. Çünkü ekimlerin yapılabilmesi için toprak sıcaklı̆ının $7-8{ }^{\circ} C^{\prime}$ ye ulaşması beklenmektedir. Bu da Mayıs ayı içerisinde mümkün olmaktadır. Haziran ayı itibarı ile hava sıcaklığının yükselmesi ve günlerin kısalmaya başlaması ile birlikte bitkiler yeterli büyüme gerçekleştiremeden çiçeklenmekte ve verimleri düşük kalmaktadır. Buna karşılık Iğdır koşullarında ekimlerin erken yapılması nedeniyle kuru şartlarda da olsa kinoa yüksek verimlere ulaşabilmektedir. Iğdır şartlarında bütün çeşitler yeterli üretim yapmışlardır. Ancak Mint Vanilla $\left(999.0 \mathrm{~kg} \mathrm{da}^{-1}\right)$, Oro de Valle $\left(917.5 \mathrm{~kg} \mathrm{da}^{-1}\right)$ ve Sandoval Mix $\left(888.5 \mathrm{~kg} \mathrm{da}^{-1}\right)$ çeşitleri daha yüksek verimli olmuşlardır. Bu çeşitler aynı zamanda ham protein verimi yönünden de ilk üç sırayı almışlardır. Red Head ( $\left.863.4 \mathrm{~kg} \mathrm{da}^{-1}\right)$, Cherry Vanilla $\left(857.0 \mathrm{~kg} \mathrm{da}^{-1}\right)$, French Vanilla $\left(846.8 \mathrm{~kg} \mathrm{da}^{-1}\right)$ ve Rainbow $\left(831.8 \mathrm{~kg} \mathrm{da}^{-1}\right)$ çeşitleri de yüksek verimli bulunmuşlardır.

\section{ÇIKAR ÇATIŞMASI}

Makale yazarları arasında herhangi bir çıkar çatışması bulunmamaktadır.

\section{YAZAR KATKISI}

Yazarlar makaleye eşit oranda katkı sağlamışlardır.

\section{TEŞEKKÜR}

Bu makale TÜBITAK tarafından desteklenen TOVAG-214O232 numaralı projenin sonuçlarından üretilmiştir.

\section{KAYNAKLAR}

Akçay, E. (2017). Farklı tuzluluk ve sulama seviyelerinin bazı kinoa (Chenopodium quinoa Willd.) genotiplerinde kök ve sürgün gelişmesine etkileri. Yüksek Lisans Tezi, Atatürk Üniversitesi Fen Bilimleri Enstitüsü Tarla Bitkileri Anabilim Dalı, Erzurum.

AOAC. 1997. Official Methods of Analysis. Association of Official Analytical Chemists. 16. ed. 3. revision. Arlington, VA, USA.

Bertero, H. D., De la Vega, A. J., Correa, G., Jacobsen, S. E., \& Mujica, A. (2004). Genotype and genotype-by-environment interaction effects for grain yield and grain size of quinoa (Chenopodium quinoa Willd.) as revealed by pattern analysis of multi-environment trials. Field Crop Research, 89, 299-318.

Bilalis, D., Kakabouki, I., Karkanis, A., Travlos, I., Triantafyllidis, V., \& Hela, D. (2012). Seed and saponin production of organic quinoa (Chenopodium quinoa Willd.) for different tillage and fertilization. Notulae Botanicae Horti Agrobotanici, 40, 42-46. 
Cardozo, A., \& Tapia, M. (1979). Valor Nutritivo. In M. Tapia, H. Gandarillos, S. Alandia, A. Cardozo \& A. Mujica (Eds.), Quinoa Y Kaniwa, Cultivos Andinos (pp. 149-192). Bogota CIID, Oficina Rgiond para la America Lotina.

Christiansen, J., Jacobsen, S. E., \& Jorgensen, S. E., 2010. Photoperiodic effect on flowering and seed development in quinoa (Chenopodium quinoa Willd.). Acta Agriculturae Scandinavica Section B Soil and Plant Science, 60, 539-544.

Curti, R. N., Andrade, A. J., Bramardi, S., Velasquez, B., \& Bertero, H. D. (2012). Ecogeographic structure of phenotypic diversity in cultivated populations of quinoa from northwest Argentina. Annals of Applied Biology, 160, 114-125.

FAO (1994). Plant Production and Protection Series. In J. E. Hernandez \& J. Leon (Eds.), Neglected Crops 1492 from a Different Perspective. No. 26, Available at http://www.fao.org/docrep/T0646E/T0646E00.htm (Access date: March 01, 2014).

FAO (2011). Quinoa: An Ancient Crop to Contribute to World Food Security. FAO Regional Office For Latin America and the Caribbean. http://www.fao.org/alc/file/media/pubs/20 11/cultivo_quinua_en.pdf. Access date: 04 May 2017.

Garcia, M., Condori, B. \& Del Castillo, C. (2015). Agroecological and Agronomic Cultural Practices of Quinoa in South America. In K. Murphy \& J. Matanguihan (Eds.), Quinoa: Improvement and Sustainable Production, First Edition (p: 25-46). John Wiley $\&$ Sons, Inc.

Garcia, M., Raes, D., \& Jacobsen, S. E. (2003). Evapotranspiration analysis and irrigation requirements of quinoa (Chenopodium quinoa) in the Bolivian highlands. Agricultural Water Management, 60, 119-134.

Geren, H. (2015). Effect of different nitrogen levels on the grain yield and some yield components of quinoa (Chenopodium quinoa willd.) under Mediterranean climatic conditions. Turkish Journal of Field Crops, 20, 59-64.

Geren, H., \& Güre, E. (2017). Farklı azot ve fosfor seviyelerinin kinoa (Chenopodium quinoa Willd.)'da tane verimi ve bazı verim unsurlarına etkisi üzerinde bir ön araştırma. Ege Üniversitesi Ziraat Fakültesi Dergisi, 54, 1-8.

Geren, H., Kavut, Y. T., \& Altınbaş, M. (2015). Bornova ekolojik koşullarında farklı sıra arası uzaklıkların kinoa (Chenopodium quinoa Willd.)'da tane verimi ve bazı verim özellikleri üzerine etkisi. Ege Üniversitesi Ziraat Fakültesi Dergisi, 52, 69-78.

Gonzalez, J. A., Gallardo, M., Hilal, M., Rosa, M., \& Prado, F. E. (2009). Physiological responses of quinoa (Chenopodium quinoa Willd.) to drought and waterlogging stresses: Dry matter partitioning. Botanical Studies, 50, 35-42.

Jacobsen, S. E. 2003. The worldwide potential for quinoa (Chenopodium quinoa Willd.). Food Review International, 19, $167-177$.

Jacobsen, S. E. (1993). Quinoa: Chenopodium quinoa Willd: A Novel Crop for European Agriculture. Department of Agricultural Science. The Royal Veterinary and Agricultural University, Denmark, 145 p.

Kacar, B. (2012). Toprak Analizleri. Nobel Akademik Yayıncılık, Yayın No: 484, Ankara.

Kaoutar, F., Abdelaziz, H., Ouafae, B., Redouane, C., \& Ragab, R. (2017). Yield and dry matter simulation using the saltmed model for five quinoa (Chenopodium quinoa) accessions under deficit irrigation in South Morocco. Irrigation and Drainage, 66(3), 340-350.

Kaya, E., \& Kızıl Aydemir, S. (2020). Determining the forage yield, quality and nutritional element contents of quinoa cultivars and correlation analysis on these parameters. Pakistan Journal of Agricultural Science, 57, 311-317.

Kır, A. E., \& Temel, S. (2016). Iğdır ovası kuru koşullarında farklı kinoa (Chenopodium quinoa Willd.) çeşit ve popülasyonlarının tohum verimi ile bazı tarımsal özelliklerinin belirlenmesi. Iğdır Üniversitesi Fen Bilimleri Enstitüsü Dergisi, 4, $145-154$.

MGM. (2017). Başbakanlık DMi Genel Müdürlüğü Meteoroloji Bültenleri, Ankara.

Pulvento, C., Riccardi, M., Lavini, A., D'Andria, R., Lafelice, G., \& Marconi, E. (2010). Field trial evaluation of two Chenopodium quinoa genotypes grown under rain-fed conditions in a typical Mediterranean environment in South Italy. Journal of Agronomy and Crop Science, 196, 407-411.

Ruiz, R. A., \& Bertero, H. D. (2008). Light interception and radiation use efficiency in temperate quinoa (Chenopodium quinoa Willd.) cultivars. European Journal of Agronomy 29, 144-152.

Spehar, C. S., \& de Barros Santos, R. L. (2005). Agronomic performance of quinoa selected in the Brazilian Savannah. Pesquisa Agropecuaria Brasileira, 40, 609-612.

Tan, M., \& Temel, S. (2017). Erzurum ve Iğdır şartlarında yetiştirilen farklı kinoa genotiplerinin kuru madde verimi ve bazı özelliklerinin belirlenmesi. Iğdır Üniversitesi Fen Bilimleri Enstitüsü Dergisi, 7, 257-263.

Tan, M., \& Temel, S. (2019). Her Yöneyle Kinoa, Önemi, Kullanılması ve Yetiştiriciliği. Iksad Publishing House, Ankara.

Tan, M., \& Yöndem, Z. (2013). İnsan ve hayvan beslenmesinde yeni bir bitki: Kinoa (Chenopodium quinoa Willd.). Alınteri, 25, 62-66.

Tan, M., \& Temel, S. (2018). Performance of some quinoa (Chenopodium quinoa Willd.) genotypes grown in different climate conditions. Turkish Journal of Field Crops, 23(2): 180-186. 
Temel, I., \& Keskin, B. (2019a). Kinoa (Chenopodium quinoa Willd.)'nın ot verimi ve bazı verim unsurlarına farklı sıra üzeri ve sıra arası mesafelerin etkileri. Iğdır Üniversitesi Fen Bilimleri Enstitüsü Dergisi, 9(1), 522-532.

Temel, I., \& Keskin, B. (2019b). Farklı sıra arası ve sıra üzeri mesafelerinin kinoa (Chenopodium quinoa Willd.)'nın besin içeriğine etkisi. Uluslararası Tarım ve Yaban Hayatı Bilimleri Dergisi, 5(1), 110-116.

Temel, S., \& Şurgun, N. (2019). Farklı dozlarda uygulanan azot ve fosforlu gübrelemenin kinoanın ot verimi ve kalitesine etkisi. Iğdır Üniversitesi Fen Bilimleri Enstitüsü Dergisi, 9(3), 1785-1796.

Temel, S., \& Yolcu, S. (2020). The effect of different sowing time and harvesting stages on the herbage yield and quality of quinoa (Chenopodium quinoa Willd.). Turkish Journal of Field Crops, 25(1), (Basımda).

Üke, Ö., Kale, H., Kaplan, M., \& Kamalak, A. (2017). Olgunlaşma döneminin kinoa (Chenopodium quinoa Willd.)'da ot verimi ve kalitesi ile gaz ve metan üretimine etkisi. KSÜ Doğa Bilimleri Dergisi, 20(1), 42-46.

Van Schooten, H. A., \& Pinxterhuis, J. B. (2003). Quinoa as an alternative forage crop in organic dairy farming. Optimal forage systems for animal production and the environment grassland science in Europe, Pleven, Bulgaria. 